\title{
Study the Duration of Steam Power Plant's Maintenance to Improve the Equivalent Availability Factor
}

\author{
Dody Awin Purjanto ${ }^{1}$, and Budi Santosa ${ }^{2}$
}

\begin{abstract}
Periodic maintenance of power plants is included in the project. Shorter project duration than scheduled indicates the success of the project. For the electricity industry, operating earlier will increase the availability index, which in turn will increase revenue. The standard maintenance work scope of the power plant owner is presented in a detailed work structure of the project as known as Work Breakdown Structure (WBS). Project scheduling is done using network technique with the Critical Path Method (CPM). All activities that are on the critical path can be done crashing to speed up work in shortening the duration of treatment. Crashing is done by utilizing the cost slope of critical activities. So information can be obtained about the costs of several possible durations. The study of power plant maintenance using a cost slope gets an accelerated duration with the smallest cost, which is 28 days. With a maintenance duration of 28 days the total cost is $3,854,670,611$ rupiahs and with an additional income of $429,643,368$ rupiah from normal income of 21,404,712,886 rupiahs.
\end{abstract}

\section{Keywords-Network, CPM, Crashing, Cost Slope.}

\section{INTRODUCTION}

The operational aspect is one of the rating factors of the power plant performance. Operational performance parameters include service to customers and increased efficiency. One indicator of service performance is the Equivalent Availability Factor (EAF). EAF is the scale of the power plant's readiness. The EAF value is a comparison between the readiness of the plant to operate, both in operating and standby conditions, against the time unit that declared.

Aside from being one of the main parameters of the performance of the power plant, EAF is also a contributor to the owner's income from the power plant. That is because the electricity business in Indonesia uses a component model. In the component model, the electricity tariff from the power plant to PLN is assessed from two aspects, namely the readiness of the power plant and the sale of electrical energy. The power plant unit has been

${ }^{1}$ Dody Awin Purjanto is with Department of Technology Management, Faculty of Business and Technology Management, Institut Teknologi Sepuluh Nopember, Surabaya, 60264, Indonesia. E-mail: dodyawinpurjanto@gmail.com.

${ }^{2}$ Budi Santosa is with Department of Industrial Engineering, Faculty of Industrial Technology, Institut Teknologi Sepuluh Nopember, Surabaya, 60264, Indonesia.E-mail: budi_s@ie.its.ac.id. paid for even though it is not operating but not in an outage condition, this condition is called standby.

EAF is affected by plant hour which includes derating and also outage. Plant hour is defined as the number of hours a generating unit operates in one year. Derating is a decrease in the ability of power plant in producing electricity compared to the initial design. Whereas the outage is defined as a condition where the power plant unit exits the electricity network owned by PLN due to not operating. The causes of outage are various, one of which is maintenance outage (overhaul) where the power plant must be shut down.

Maintenance activities are intended to maintain operational continuity and performance of the power plant system so that it runs as expected. Periodic maintenance activities affect the EAF value of the power plant, so needed a maintenance planning system in order to produce the availability of the optimum power plant.

Faster maintenance completion time will allow the power plant to resume operations ahead of the planned schedule. With the operation of the power plant earlier than planned it will increase the value of the EAF. Meeting the EAF target triggers the power plant maintenance service company trying to be able to complete its work faster than the standards set by the major component manufacturer.

Periodic maintenance of power plants is classified as a project so that arrangements are needed in order to achieve the agreed targets between the implementer and the owner. Paying more attention to the completion duration of maintenance work does not mean ignoring quality or even cost factors. The owner determines the scope of maintenance work with a predetermined budget to achieve quality, time and cost targets.

Project scheduling helps show the relationship between each activity to the overall project. In addition, project scheduling can identify the relationships that must take precedence between activities in the project and can show the estimated duration of completion of each works. Critical Path Method (CPM) which is one of the scheduling techniques that is widely used in projects. The CPM assumes that the duration of the activity is known with certainty. CPM on project management emphasizes more on the right cost.

CPM can also be applied to periodic maintenance projects for power plants. Using CPM is expected to 
determine the overall project cost minimization with afaster completion duration. Analysis of the project completion time is carried out on activities that are on the critical path of the project by calculating the total cost of each. These costs include direct costs and indirect costs. The completion time cost trade off will produce a minimum point, both in terms of time and in terms of costs, for the maintenance project.

\section{LitERATURE REVIEW}

\section{A. Steam Power Plant}

The main systems in electricity generation include generators and turbines. The generator functions to convert mechanical energy into electrical energy. While the turbine is the initial drive of the generator. Power plants that use steam as a working fluid to turn turbines are known as steam power plants.

Power plants also require maintenance. Maintenance in the form of maintenance work activities carried out on steam power plant equipment with the aim that the equipment can be operated optimally, reliably, efficiently, safely and can reach the life time as planned.

\section{B. Project}

A project may be defined as a series of related jobs usually directed toward some major output and requiring a significant period of time to perform[1]. The project is a temporary effort carried out to produce a unique product or service[2]. From these two understandings, a project has several important characteristics contained therein.

Projects are temporary, meaning that each project always has a clear schedule of when to start and when to finish. A project ends if the objectives have been achieved or there is no need for the existence of the project. Projects are unique in that each project produces a certain product, solution, service or output that is different from one another with similar products or services. No two projects are one hundred percent the same. Progressive elaboration is a project characteristic related to the two previous concepts temporary and unique. Each project consists of steps that continue to develop and continue until the project ends. Each step makes the project objectives clearer.

These characteristics that distinguish the activities of a project from routine operational activities. Operational activities tend to be continuous and repetitive, while project activities are temporary and unique. In terms of objectives, project activities will stop when the goals have been achieved. While operational activities will continue to adjust its objectives so that work continues[3].

There are four important things that affect the success of a project[4], among others:

1) Project management through a project life cycle mechanism;

2) Monitoring and controlling the project schedule, project budget, project quality, and risk in a project;
3) Integrating or integrating project management tools and methods for the purpose of increasing productivity, team performance and communication; and

4) Management's commitment in supporting the success of the project.

The definition of project success has changed over the past twenty years, where the project is said to include criteria[5]:

1) Within the allocated time period,

2) In the budgeted costs,

3) At the right level of performance or specification,

4) By acceptance by customers / users,

5) With the change in the minimum scope agreed upon,

6) Without disrupting the organization's main workflow, and

7) Without changing the company base

Time is an important parameter in a project at this time[6]. Gupta and Starr (2014) add that it aims to determine the duration of the project with the target of achieving the shortest project completion time by controlling activities that are included in the critical path.

\section{Project Management}

Project management is the application of knowledge, skills, tools and techniques in project activities to meet project needs[2]. Project management is the planning, monitoring and control of all aspects contained in a project, as well as the motivation therein to achieve project goals with the time, cost, quality and performance that has been determined[7]. In its implementation, each project is always limited by constraints that are interdependent and is called a triangle project constraint that is the scope of work (scope), time and cost. Where the balance of the three constraints will determine the quality of a project[3].

The project scope discusses the types and limitations that exist in a project. Scope is the main thing in a project because it gives a direct impact on two other factors, namely the time and cost of project work. The greater the scope of the project will also increase the processing time so that the impact on increasing project costs.

Time is the main target of a project in general. In this factor, the duration of time needed to complete a project is determined. Some projects are forced to be completed at a certain time without considering the increase in costs, this makes the time on the project a crucial one.

Cost is a factor in the project in determining how much it will cost for the project. The cost factor is influenced by two previous factors (scope and time). The greater the scope of work and the longer the completion time, the greater the cost of a project.

Changes in one or more of these factors will affect at least one other factor[2]. Triple constraint optimization (scope, time \& cost) is needed to achieve balance in order to meet project targets. 


\section{Scheduling Technique}

Scheduling can be interpreted as a time division planning activity and inter-work relationship in a project. The scheduling function on a project can help[8], among others:

1) Demonstrate the relationship of each activity to other activities and to the whole project;

2) Identifying relationships that should take precedence between activities;

3) Demonstrate realistic cost and time estimates for each activity;

4) Help find out things that might hamper a project.

There are several scheduling techniques that can be chosen according to the conditions of the project to be handled. The search for tools in effective project management has resulted in the development of various scheduling techniques. The scheduling technique can be classified into two broad categories namely, Bar Charts and Networks.

\section{E. Bar Chart: Gantt Chart}

One popular project scheduling approach is the Gantt diagram, which is a low-cost method that helps managers ensure that all activities have been planned, a sequence of performance has been calculated, estimated time the activities have been recorded, and the entire time the project has been made[9]. Gantt Chart is a tool for planning the scheduling and monitoring of activities on a project, communicating the activities that must be carried out and also the status of their implementation. The method developed by Henry Laurence Gantt in 1910 was basically a description of the planning, scheduling and monitoring of the progress of each activity or activity on a project.

In the Gantt Chart can also be seen the sequence of activities or tasks that must be done based on the specified time priority. The work to be carried out is enumerated on the vertical axis while the time duration between the two activities is described on the horizontal axis[10]. Gantt Chart is generally used for simple scheduling or projects whose activities are not very related or small projects, whereas for scheduling complex projects using a network[11].

\section{F. Network}

Network is a flow diagram showing the sequence of operations of a process[12]. Each individual operation is known as an activity and each meeting point or transfer stage between one activity and another is a node. Activities are drawn in a straight line while nodes are in circles.

Network is one of the most popular quantitative techniques, because this model visually describes the system being analysed. This makes it easier for analysts to understand and have clearer interpretations of the system. Starting around 1957, two similar approaches to planning and tracking large-scale project networks namely the
Program Evaluation Review Technique (PERT) and the Critical Path Method (CPM)[6].

The two techniques, PERT and CPM, identify project critical paths with activities that cannot be delayed, and also show activities with a float that can be slightly delayed without extending the project completion time so as to estimate probabilistic time from the CPM and be able to trim PERT network[13].

PERT is oriented on the project time element and uses probabilistic activity time estimates to assist in determining the probability that the project can be completed on a certain date while CPM uses deterministic activity time estimates and is designed to control aspects of project time and cost, specifically the trade-off between time and costs[13]. Also stated in the reference is that activity on the CPM can be accelerated with additional costs as compensation.

\section{G. Critical Path Method (CPM)}

CPM uses the estimated time of deterministic activity. CPM is used if the time of completion of each activity is known with certainty, where the level of deviation of the realization of the completion compared to the plan, is relatively small or can even be ignored. Whereas PERT is used in activities where the completion time is uncertain because it has never been done before or the activity has a wide variation in estimated completion time. CPM is more widely used than scheduling using other network methods. It is based on the concept of a critical path and is designed to focus the time and resources, especially costs, needed to complete project activities.

The first step in CPM is to determine the activity details. Details of activities that must be carried out in a project, added information about the duration and identification of prerequisites of previous activities that must be completed first.

The second step determines the order of activities and draw it in the form of a network. Some activities can only be started with very dependent on the completion of other activities that preceded it. The relations between these activities must be identified and described sequentially in the form of points and lines.

Step three sets out the estimated completion time for each activity. The time needed to complete each activity can be estimated using past experience or estimates from practitioners. CPM does not take into account variations in completion time, so only one estimate will be used to estimate the time of each activity.

The fourth step identifies the critical path (CP). CP is the path that has the longest duration on the network. The activity located on the $\mathrm{CP}$ is delayed, so the overall project completion time will also be delayed. In a path other than $\mathrm{CP}$, there will be a loose time or slack time, the time when an activity can be postponed without delaying the completion of the project as a whole. 
The fifth step is to update the CPM diagram. As the project progresses, the time to complete the activity can be updated in accordance with the acquisition of new information and assumptions. A new CP may appear and a change in the shape of the network is very likely to be done.

Some of the benefits of CPM include:

1) Provide a graphical display of the flow of activities of a project,

2) Predict the time needed to complete a project,

3) Shows the flow of activities which are important to consider in maintaining the project completion schedule.

Weaknesses in the CPM are in the use of one estimated number of completion times for each activity. If more complex project planning is needed, the PERT method with three variants of estimated time will provide a more open alternative estimate for project completion time.

Critical path (CP) is the path that has the longest time of all paths starting from the initial event to the last event in the activity network diagram. So that a CP shows critical activities in a project where if there is a delay in the activity it will affect the overall completion time of the project. An activity is called uncritical if it has a delay. Delay in uncritical activities is known as slack or float time.

The concept of float time provides flexibility as a modification medium for scheduling a project to complete certain jobs so that there is a period of time where the duration of the activity can exceed the plan but does not affect the CP and the overall project completion schedule.

\section{H. Work Breakdown Structure (WBS)}

Analysis of activities with a network diagram begins with preparing and compiling a list of activities or work in the project. After the entire scope is identified, project work can be divided into smaller work elements where the process hierarchy is known as WBS[14]. WBS as a project map helps ensure that all elements of work are identified and integrated as a basis for controlling the project

In WBS, each activity is identified including the activities that must precede it (predecessor) and how long the activity must be carried out (duration). The duration of each activity will provide information about the shortest and longest time of all activities in the project, which are sequentially known as the earliest event time and the latest event time.

\section{Previous Research}

Research on the duration of the project or its acceleration has been carried out by many researchers with a variety of methods and approaches to analysis. The following will be discussed briefly about some of these studies.

Stefanus, Wijatmiko and Suryo (2017) conducted an acceleration analysis of project completion times using the fast-track method and crash program. The purpose of the analysis is to determine the acceleration of time and costs that can be saved on the Bojonegoro Phase II Dewarna Hotel project. To speed up the project completion time to avoid delays, the fast-track and crash program methods are used to compare the results. In terms of costs with the fasttrack method requires a fee of 26,376,440,619 rupiahs, whereas with the crash program method requires a fee of 26,504,146,817 rupiahs. Both methods are able to reduce costs due to project delays which initially amounted to $27,059,140,712$ rupiahs. In terms of the cost of the fasttrack method it is cheaper, but has a greater risk because if one job that is on a critical track experiences delays it will affect other jobs.

Priyo and Aulia (2015) conducted a study by applying the time cost trade off method to a construction project with the object of study in the Indonesian Building construction project. This study aims to get a trade-off between costs and project acceleration because there are delays at the start of the project. The research concludes that the best option for overcoming a delay is to add work time (overtime), because the project costs (including overtime pay) are cheaper than the costs to be paid if the project fails and must pay the penalty.

Arianie and Puspitasari (2017) plan project management to improve the efficiency and effectiveness of company resources. The project planning was prepared using Work Breakdown Structure (WBS), Critical Path Method (CPM) and Program Evaluation and Review Technique (PERT). With these three tools, project management can predict a project acceleration (crashing). The project management plan carried out resulted in an estimated acceleration of project work over a period of six days, with an additional cost of 2.8 million rupiahs.

Saputra, Munawir and Wijatmiko (2017) analyzed the acceleration of activities on road projects using the fast track, crash program and what-if methods. The project is experiencing delays, with conditions in the 27th week the realization of achievement is only about $13 \%$ of the $53 \%$ plan. This study aims to determine the acceleration of implementation, to evaluate the effectiveness of acceleration, and to evaluate the implementation of road projects based on time and cost control. The fast track method can speed up 78 days, the program crash method can speed up 31 days, and the what-if method can speed Fup to 7 days from before acceleration, which is 110 days late. These three methods cannot speed up the project based on the plan. The fast track method is the fastest approach to the initial plan. Then the combination of acceleration between fast track and crash program produces the total duration on schedule. The conclusion is that a combination of methods can return a schedule according to plan.

Winanto, Kustamar and Iskandar (2013) conducted a study to overcome the delay in building construction using the fast track method. In further research to find out the 
amount of costs that can be saved by using the fast track method. The research method used is to use scheduling with CPM, accelerate activities that are on critical trails, do fast tracks on critical trails until they get saturated time and get optimum time at minimum cost. From the results of the study, it was found that the amount of time obtained was 23 calendar days or $50.0 \%$ of the normal time 46 days or 23 days faster and the cost saved was 48,325,539 rupiahs of the normal cost of 2,029,672,351 rupiahs or a saving of $2.38 \%$.

Frederika (2010) analyses the acceleration of project implementation by adding optimum working hours. The calculation starts with finding a critical trajectory using Microsoft Project then crashing to get the cost slope of activities that are on the critical trajectory, then an analysis using the Time Cost Trade Off Analysis method. Acceleration with the optimum cost is obtained at the addition of one working hour and the optimum time is obtained at the addition of two working hours.

However, from the literature study, there is no similarity in the object of research in the form of the duration of periodic inspection of power plant units. This is the basis of this research approach to study the duration of the project in general. From the brief description of the previous research in the sub-chapter above, a comparison table can be made as shown in Table 1 . below. Where in the table will make it easier to determine the location of the differences in this study with previous studies.

TABLE 1.

COMPARISON (POSITION) OF THIS STUDY WITH PREVIOUS STUdIES

\begin{tabular}{|c|c|c|c|c|c|c|c|}
\hline \multirow[b]{2}{*}{ 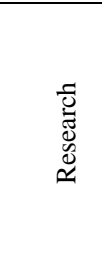 } & \multicolumn{2}{|c|}{$\begin{array}{c}\text { Object of } \\
\text { Project }\end{array}$} & \multicolumn{3}{|c|}{$\begin{array}{c}\text { Reduction of Duration } \\
\text { Method }\end{array}$} & \multicolumn{2}{|c|}{ Analysis } \\
\hline & 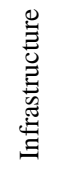 & 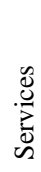 & 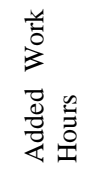 & 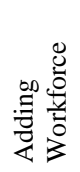 & 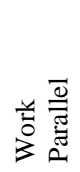 & 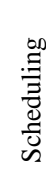 & $\bar{v}$ \\
\hline [15] & $\bullet$ & & $\bullet$ & & $\bullet$ & & $\bullet$ \\
\hline [16] & $\bullet$ & & • & • & & $\bullet$ & - \\
\hline [17] & & $\bullet$ & & - & & - & - \\
\hline [18] & $\bullet$ & & - & - & $\bullet$ & $\bullet$ & $\bullet$ \\
\hline [19] & $\bullet$ & & & & $\bullet$ & $\bullet$ & $\bullet$ \\
\hline$[20]$ & $\bullet$ & & 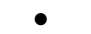 & & & $\bullet$ & $\bullet$ \\
\hline Current & & $\bullet$ & - & $\bullet$ & - & - & $\bullet$ \\
\hline
\end{tabular}

\section{Methodology}

Broadly speaking, this research consists of four stages. These stages include literature study, data collection, data processing, analysis, finally conclusions and suggestions. Data processing consists of making WBS and network, also determining CP. While the analysis phase consists of the calculation of trade-offs and savings obtained by the owner. These stages are illustrated in Figure 1.

The literature used as the basis of this research is project management in which there are project planning and control, scheduling, networking, acceleration of project duration (crashing) and also trade-offs between project costs and time.

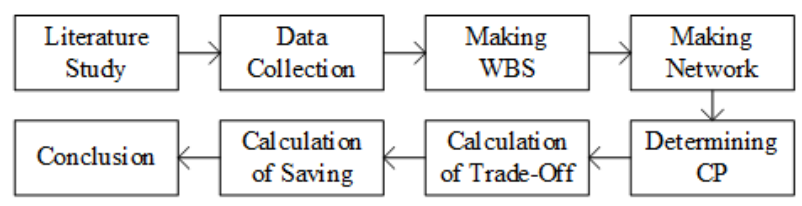

Figure 1. Research Flow Chart

Data that can support this research include maintenance job standards, the number of workers involved, labour rates, and also the list of equipment used in the maintenance project. The list of equipment will have an influence in determining the duration of work and the division of teams in maintenance projects.

Work duration data is also obtained from the planning field which usually still refers to the standard maintenance duration of the manufacturer. The technicians doing work in their respective fields were also asked for data regarding the time completion of the work while involved in the maintenance project.

The data processing stage begins with creating a maintenance project WBS in accordance with the standard job of the owner. WBS has been created as a basis for creating a network of each project activity. The network that has been built and has been equipped with information on the duration of the project activity will provide information about the critical trajectory of the power plant maintenance project.

In critical activities (activities that are on the critical path) are calculated about the costs. Starting from the normal duration to the shortened duration that allows for these activities. The shortest duration is based on the survey results of experienced technicians in power plant maintenance. The basis for calculating these costs is divided into two categories, direct costs and indirect costs. Direct costs include labour costs. While indirect costs are all costs related to logistics during the maintenance project.

The study was conducted in order to shorten the duration of maintenance of power plants to increase the level of availability. Analysis is carried out on the results of data processing related to project costs. Analysis of the costs incurred for each duration of the results is calculated based on critical activities in the project.

The conclusion explains the things that have been discussed in the previous chapter that relate to the question formulation of the problem. Some things that can be concluded in the research process from data collection to final analysis are also presented in this conclusion.

The implementation of this research certainly gives positive results, and there are also things that are lacking in a project undertaken. Weaknesses and strengths in this research will be a suggestion for project managers or even further research needs to get better results. 
The $1^{\text {st }}$ International Conference on Business and Management of Technology (IConBMT)

August 3rd 2019, Institut Teknologi Sepuluh Nopember, Surabaya, Indonesia

\section{RESUlT AND DISCUSSION}

The object of this research is the periodic maintenance project of the main fired steam power plant in the form of natural gas. The scope of periodic maintenance is the mean inspection (ME). There are seven standard job jobs on the maintenance and fifty tasks in standard duration for 30 days. These tasks are mentioned in Table 2.

TABLE 2.

TASKS ON the MEAN INSPECTION OF POWER PLANTS

\begin{tabular}{|c|c|}
\hline Task & ID \\
\hline Maintenance of MSV & G \\
\hline Maintenance of CV & $\mathrm{H}$ \\
\hline Maintenance of CRV & I \\
\hline Maintenance of LP Turbine & $\mathrm{J}$ \\
\hline Maintenance of HIP Turbine & $\mathrm{K}$ \\
\hline Maintenance of Crossover Pipe & $\mathrm{L}$ \\
\hline Maintenance of Condenser \& Ball Cleaning System & M \\
\hline Maintenance of Gland Steam System & $\mathrm{N}$ \\
\hline Maintenance of LP Turbine Bypass System & $\mathrm{O}$ \\
\hline Maintenance of Air Ejector (SJAE, SAE) & $\mathrm{P}$ \\
\hline Maintenance of CP (1 unit) & $\mathrm{Q}$ \\
\hline Maintenance of LPH (1 unit) & $\mathrm{R}$ \\
\hline Maintenance of ERCV & $\mathrm{S}$ \\
\hline Maintenance of Deaerator & $\mathrm{T}$ \\
\hline Maintenance of MOT \& Oil Conditioner & $\mathrm{U}$ \\
\hline Maintenance of Seal Oil Unit & $\mathrm{V}$ \\
\hline Maintenance of Cooling Water System & $\mathrm{W}$ \\
\hline Re-arrangement of Tube $2^{\text {nd }} \mathrm{SH}$ & $\mathrm{Z}$ \\
\hline Tube Boiler RLA & AA \\
\hline Maintenance of Main Steam Pipe & $\mathrm{AB}$ \\
\hline Maintenance of GIF & $\mathrm{AC}$ \\
\hline Maintenance of Gas Duct & $\mathrm{AD}$ \\
\hline Maintenance of BFP (1 unit) & $\mathrm{AE}$ \\
\hline Maintenance of Booster Pump & $\mathrm{AF}$ \\
\hline Maintenance of Air Duct & AG \\
\hline Maintenance of FDF (1 unit) & $\mathrm{AH}$ \\
\hline Maintenance of SCAH & AI \\
\hline Maintenance of Air Heater & AJ \\
\hline Maintenance of Burner System & AK \\
\hline Maintenance of valve HP, steam, \& burner drain system & $\mathrm{AL}$ \\
\hline Maintenance of LSB R \& L & $\mathrm{AM}$ \\
\hline Maintenance of HPH (1 unit) & AN \\
\hline Maintenance of Cold/Hot Reheat Pipe \& Damper & $\mathrm{AO}$ \\
\hline Maintenance of PCV & AP \\
\hline Maintenance of Header & AQ \\
\hline Maintenance of Blowdown System & AR \\
\hline Maintenance of Steam Drum & AS \\
\hline Maintenance of Generator & AT \\
\hline Maintenance of AVR & $\mathrm{AU}$ \\
\hline
\end{tabular}

\begin{tabular}{ll} 
Maintenance of Electric Control Panel & AV \\
Maintenance of Motors & AW \\
Maintenance of Transformer & AX \\
Maintenance of ABS & AY \\
Maintenance of ABC & AZ \\
Maintenance of BLC & BA \\
Maintenance of TSI \& D-EHC & BB \\
Maintenance of TLC & BC \\
Maintenance of CWP & BE \\
Maintenance of Bar \& Travelling Screen & BF \\
Maintenance of Intake \& Pressure Tunnel & BG \\
\hline \hline
\end{tabular}

There are a number of supporting activities in completing the standard job, starting from post-shut down to re-operation. These activities are included in the WBS that will be arranged because it requires time (has a duration) which is included in the ME standard duration. These activities include the following in Table 3.

TABLE 3.

Supporting Activities on the MeAn Inspection Of POWER Plants

\begin{tabular}{ll}
\hline \hline Activities & ID \\
\hline Shut Down & A \\
Cooling Down & B \\
Characteristic (Before) & C \\
Cross-over pipe lifting & D \\
Turbine housing, lagging \& isolation lifting & E \\
Turning device \& pedestal lifting & F \\
Boiler cooling down & X \\
Scaffoldings installation on main boiler & Y \\
Assembly cross-over pipe, turning device \& pedestal & BI \\
Assembly MOP \& pedestal, bearing cover & BJ \\
Filling Hot well & BK \\
Boiler Hydrostatic Test & BL \\
Flushing & BM \\
Characteristic (After) & BN \\
Interlock Test & BO \\
Start Up (Firing) & BQ \\
\hline \hline
\end{tabular}

Then the activities are arranged into a work breakdown structure (WBS) in the form of a network as shown in Table 4.

TABLE 4.

NETWORK ON THE MEAN INSPECTION OF POWER PLANTS

\begin{tabular}{ccc}
\hline \hline ID & Duration (Days) & Predecessor \\
\hline A & 0 & - \\
B & 3 & A \\
C & 2 & B \\
D & 1 & E
\end{tabular}


A

C, D

C

C

C

D

F

F

B

P

B

O

$\mathrm{P}$

P

$\mathrm{N}$

A

C

C

\begin{tabular}{ccc} 
BB & 20 & C \\
BC & 18 & C \\
BD & 2 & BD \\
BE & 21 & BD \\
BF & 20 & BD \\
BG & 15 & BE, BF, BG \\
BH & 1 & L, BJ \\
BI & 1 & K, J \\
BJ & 1 & M, Q, R, AW \\
BK & 1 & Z, AA, AR, AS, T, BK \\
BL & 4 & BJ, V, BC, U \\
BM & 3 & BL, S, AV, G, H, I, BB, BI, BM \\
BN & 1 & AP, BN, AT, AZ, AX, BA, W \\
BO & 1 & BO, BH \\
& & AF, AOs \\
BP & 1 & Aotal \\
\hline \hline
\end{tabular}

There are activities that have a critical time in their implementation. These critical activities are divided into five critical trajectories, including:

1) $\mathrm{A}-\mathrm{B}-\mathrm{C}-\mathrm{F}-\mathrm{K}-\mathrm{BJ}-\mathrm{BM}-\mathrm{BN}-\mathrm{BO}-\mathrm{BP}$;

2) $\mathrm{A}-\mathrm{X}-\mathrm{AI}-\mathrm{BO}-\mathrm{BP}$;

3) $\mathrm{A}-\mathrm{AW}-\mathrm{BK}-\mathrm{BL}-\mathrm{BN}-\mathrm{BO}-\mathrm{BP}$;

4) $\mathrm{A}-\mathrm{B}-\mathrm{M}-\mathrm{BK}-\mathrm{BL}-\mathrm{BN}-\mathrm{BO}-\mathrm{BP}$;

5) $\mathrm{A}-\mathrm{B}-\mathrm{AU}-\mathrm{AV}-\mathrm{BN}-\mathrm{BO}-\mathrm{BP}$.

Cost slope helps determine the most efficient duration associated with project costs. Because there will be a point in the duration of the project that has a minimum cost. Reducing the duration of a project by reducing the duration of a critical activity starts from the activity with the lowest cost slope. In practice in the field, this reduction in duration by increasing working hours. Adding work hours can be done in the form of overtime or shift work patterns. The addition of working hours will add direct costs to the project. This direct cost addition is then used to calculate the cost slope.

There are two types of costs associated with steam power plant ME's work activities, namely direct costs and indirect costs. Direct costs include the cost of supporting labour along with overtime wages. These overtime costs are included for engineers involved in this project. The supporting workforce has two classifications, including senior technicians and junior technicians. Whereas indirect costs include all costs related to logistics (food, drinking water, clean water, shelter, etc.) and secretariat (stationery, communication costs and others).

\section{CONCLUSION}

Shortening the duration of a maintenance project will add direct costs to the project. But it will reduce indirect costs. Next calculate the total project cost with the results shown in Table 5. 
The $1^{\text {st }}$ International Conference on Business and Management of Technology (IConBMT)

August 3rd 2019, Institut Teknologi Sepuluh Nopember, Surabaya, Indonesia

TABLE 5.

CALCUlation OF TOTAL PROJect COSTS

\begin{tabular}{cccc}
\hline \hline $\begin{array}{c}\text { Duration } \\
\text { (Days) }\end{array}$ & $\begin{array}{c}\text { Direct Cost } \\
\text { (IDR) }\end{array}$ & $\begin{array}{c}\text { Indirect Cost } \\
\text { (IDR) }\end{array}$ & $\begin{array}{c}\text { Total Cost } \\
\text { (IDR) }\end{array}$ \\
\hline 30 & $1,930,830,964$ & $1,978,987,500$ & $3,909,818,464$ \\
29 & $1,957,332,219$ & $1,913,021,250$ & $3,870,353,469$ \\
28 & $2,007,615,611$ & $1,847,055,000$ & $3,854,670,611$ \\
27 & $2,101,808,117$ & $1,781,088,750$ & $3,882,896,867$ \\
26 & $2,204,271,790$ & $1,715,122,500$ & $3,919,394,290$ \\
\hline \hline
\end{tabular}

Indirect costs actually go down when the duration of the project is shortened, this is the opposite of direct costs. Figure 2 below is a total cost graph from Table 5.

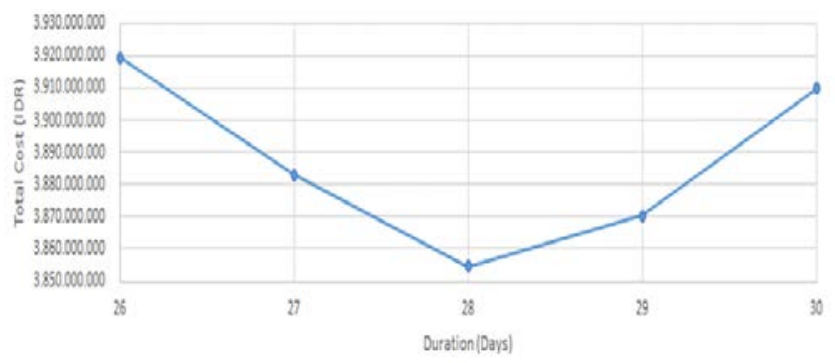

Figure 2. Project Total Cost Graph

At the beginning of the year, the owner had to declare a periodic maintenance schedule for the generating unit owned and its duration. By declaring it can be calculated income from the number of operating hours in a year.

Conditions where the actual income is greater than declare, the owner will get additional benefits. Greater realization income one of which occurs when the duration of maintenance realization is shorter than the planned duration. The following Table 6 shows the results of income simulation based on declare and realization of periodic maintenance duration using the owner's official page.

TABLE 6.

CALCULATION OF TOTAL OWNER'S INCOME

\begin{tabular}{cccc}
\hline \hline $\begin{array}{c}\text { Duration } \\
\text { (Days) }\end{array}$ & $\begin{array}{c}\text { Declare } \\
\text { (IDR) }\end{array}$ & $\begin{array}{c}\text { Realization } \\
\text { (IDR) }\end{array}$ & $\begin{array}{c}\text { Profit } \\
\text { (IDR) }\end{array}$ \\
\hline 30 & $21,404,712,886$ & $21,404,712,886$ & 0 \\
29 & $21,404,712,886$ & $21,619,534,570$ & $214,821,684$ \\
28 & $21,404,712,886$ & $21,834,356,254$ & $429,643,368$ \\
27 & $21,404,712,886$ & $22,049,177,938$ & $644,465,053$ \\
26 & $21,404,712,886$ & $23,159,090,000$ & $1,754,377,115$ \\
\hline \hline
\end{tabular}

Figure 3 below is a profit graph from Table 6.

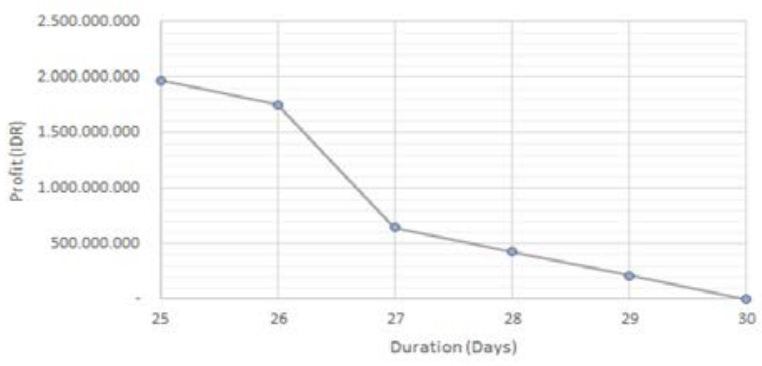

Figure 3. Profit Graph

\section{ACKNOWLEDGEMENT}

Shortening of the maximum duration of up to 26 days from the standard 30 days. Based on calculations using the cost slope, it is found that the periodic maintenance of the power plant, the scope of the mean inspection, with a duration of 28 days is the smallest point in terms of costs of $3,854,670,611$ rupiahs.

With a maintenance duration of 28 days, the owner gets an additional income of 429,643,368 rupiahs from the planned revenue of 2,1404,712,886 rupiahs, if maintenance is in accordance with the 30 days standard.

\section{REFERENCES}

R. B. Chase, F. R. Jacobs, and N. J. Aquilano, Operations Management for Competitive Advantage. New York: McGrawHill/Irwin, 2006.

[2] P. M. Institute, A Guide to The Project Management Body Of Knowledge (PMBOK Guide). Pennsylvania: Management Institut, Inc, 2000.

[3] S. Budi, Manajemen Proyek Konsep \& Implementasi. Yogyakarta: Graha Ilmu, 2004.

[4] I. Heryanto and T. Triwibowo, Manajemen Proyek Berbasis Teknologi Informasi, Revisi. Bandung: Informatika, 2013.

[5] H. Kerzner, Project Management: A systems Approach to Planning, Scheduling and Controlling, 10th ed. John Wiley \& Sons, 2009.

[6] S. Gupta and M. K. Starr, Production and Operations Management Systems. Boca Raton: CRC Press, Taylor \& Francis Group, 2014.

[7] B. Hedeman and R. Seegers, PRINCE2(TM) 2009 Edition - A Pocket Guide, 2009th Ed. Zaltbommel: Van Haren Publishing, 2009.

[8] J. Heizer and B. Render, Operations Management, 10th ed. Upper Saddle River New Jersey: Prentice Hall, 2011.

[9] H. A. Rusdiana, Manajemen Operasi I. Bandung: CV Pustaka Setia, 2014.

[10] R. Klein, Scheduling of Resource-Constrained Projects, vol. 10. Boston, MA: Springer US, 2000.

[11] A. Al Fattah, "Analisa Perubahan Pola Beban Kerja Berdasarkan Value Added, Non-Value Added, Necessary Added Aktivitas Overhaul dan Dampaknya Terhadap Aspek Kualitas, Biaya, dan Waktu,” Institut Teknologi Sepuluh Nopember, 2018.

[12] A. Lester, Project Management, Planning and Control. Amsterdam: Elsevier/Butterworth-Heinemann, 2007.

[13] J. R. Meredith and S. J. Mantel, Project Management: A Managerial Approach, 7th ed. Hoboken, New Jersey: John Wiley \& Sons, Inc, 2009.

[14] E. W. Larson, C. F. Gray, and C. F. Gray, Project Management: The Managerial Process. New York: McGraw-Hill Irwin, 2011.

[15] Y. Stefanus, W. Indradi, and E. A. Suryo, “Analisis percepatan 
The $1^{\text {st }}$ International Conference on Business and Management of Technology (IConBMT)

August 3rd 2019, Institut Teknologi Sepuluh Nopember, Surabaya, Indonesia

waktu penyelesaian proyek menggunakan metode fast-track dan crash program,” J. Media Tek. Sipil, vol. 15, no. 1, p. 76, 2017. M. Priyo and M. R. Aulia, "Aplikasi metode time cost trade off pada proyek konstruksi: studi kasus proyek pembangunan Gedung Indonesia,” J. Ilm. Semesta Tek., vol. 18, no. 1, pp. 3034, 2015.

[17] G. P. Arianie and N. B. Puspitasari, "Perencanaan manajemen proyek dalam meningkatkan efisiensi dan efektifitas sumber daya perusahaan (Studi kasus: Qiscus Pte. Ltd),”J@ti Undip J. Tek. Ind., vol. 12, no. 3, pp. 189-196, Sep. 2017.

[18] A. Saputra, A. Munawir, and I. Wijatmiko, "Analisis percepatan aktifitas pada proyek jalan dengan menggunakan metode fast track, crash program, dan what-if,” Rekayasa Sipil, vol. 11, no. 1, pp. 1-8, 2017.
[19] K. Kustamar, T. Iskandar, and E. Winanto, "Penerapan metode fast track untuk percepatan waktu pelaksanaan proyek pembangunan gedung ICUI, ICCU, dan NICU RSU Dr. Saifyul Anwar Malang,” J. Tek. Sipil INFO MANPRO, vol. 7, no. 1, pp. 1-11, Jul. 2017.

[20] A. Frederika, "Analisis percepatan pelaksanaan dengan menambah jam kerja optimum pada proyek konstruksi (Studi kasus: Proyek pembangunan super villa, Peti Tenget-Badung)," J. Ilm. Tek. Sipil, vol. 14, no. 2, pp. 113-126, 2010. 